\title{
The Structure and Function of Keywords in the Development of Civil Wars: Opportunities for Peace Building?
}

\author{
Jon D. Unruh \\ McGill University
}

\begin{abstract}
With intrastate wars the prevailing form of armed conflict, attention is focusing on analytical approaches able to provide insights into the drivers of conflict and the prospects for peacebuilding at the level of discrete populations. While 'narratives of grievance' play a strong role in the development of conflicts, unexamined in the literature is why there is pervasively a high degree of ambiguity, confusion, and multiple meanings with regard to the terms, concepts and understandings that describe the central dilemmas around which narratives of grievance consolidate. This article examines this question for three cases of civil war (Darfur, Colombia, Yemen) in which land rights is the key dilemma. Using the 'keywords' approach, the argument is made that, keywords are prevalent in civil conflicts, can be observed well before a conflict begins, and can provide the basis for the development of tools for peace-building.
\end{abstract}

\section{Introduction}

While narratives of grievance are recognized as a primary driver of civil wars, less examined in the literature is the development of the central dilemma ${ }^{1}$ that such narratives necessarily coalesce around for discrete populations. Such dilemmas and how they fit into ideas of history, injustice and aspiration arguably drive grievance-based narrative development in the first place. As a central dilemma in a society becomes aggravated in the period prior to civil conflict, its different interpretations become aligned with different segments of society and then the different sides in the armed conflict (Unruh and Abdul-Jalil, 2014). This alignment is usually connected to perceptions of justice and injustice, livelihoods, local to national institutions and interpretations of politics and history (Dahlman, 2005). However an important pattern that this author has observed in pursuing research, practice, and policy work on war-affected land and property rights in 18 countries over the past 25 years, is that there is very often a great deal of ambiguity, confusion, and multiple definitions and understandings with regard to the terms, concepts and meanings surrounding such central dilemmas. Why is this? And might there be insights in an explanation that could prove useful to peace-building?

This paper examines these questions in three cases of armed conflict, with land rights the central dilemma in all cases. The analytical approach uses a set of concepts known as 'keywords', initially following Williams (1985) and then further elaborated by Durant (2008), Bennet et. al., (2005), Mitchell and Breitbach (2006) and others; including those who have applied Williams' keyword concepts to communication (Jones and Holmes 2011), social and cultural

\footnotetext{
${ }^{1}$ Such 'central dilemmas' are the set of closely related problems that together constitute the crux of narratives of grievance (Unruh and Abdul-Jalil 2014).
} 
history (Crowley, 2012), culture (Wierzbicka, 1997), and politics (Brooker, 2011). While it was not the intent of Williams (1985) and others interested in keyword analyses to examine the development of armed conflict--evidenced by the lack of literature on the topic--the current analysis argues that, 1) the existence and importance of keywords is widespread in conflicts where land issues are acute, 2) the keywords approach can be used to explain the confusion and ambiguity that frequently surround important dilemmas in certain types of civil wars, 3) keywords allow insight to be gained into how certain 'alignments' occur in the development of land rights-related conflict, 4) they can clarify what some of the important underlying issues are in civil wars, 5) they are observable well prior to the onset of armed conflict, and 6) they can provide the basis for the potential development of technical tools in peace-building.

The role of rights to lands in armed conflict has been linked to a wide range of fundamental reasons for fighting. From indigenous, autochronous and ethnonationalist claims, to religious, resource, security, and livelihood assertions, to (re)settlement, political, restitution, environmental change and extremest interests; the broad spectrum of land rights in war-affected scenarios are a reflection of an array of volatile problems that become reasons for engaging in armed conflict (e.g., Unruh and Williams, 2013; Sait and Lim, 2006; Toal and Dahlam, 2011). Jensen et. al., (2013) found that in all but three of over 30 wars occurring between 1990 and 2009, land rights played a major role. And Alden-Wily (2008) concludes that over two-thirds of ongoing armed conflicts globally are driven at least in-part by contested rights to land. While there are certainly other dilemmas that play significant roles in the onset of civil conflicts, land rights is a common one and will be the lens used in this analysis. Home (2003) first linked the concept of Williams' keywords to conflict and land by briefly describing a keyword cluster important in the Israel/Palestinian conflict. While instructive, the Israel/Palestinian case is different from the conflicts examined below, in that it is less of a civil conflict and closer to a national one, and the social debates regarding land rights are not engaged in by the populations on both sides of the conflict as they are in civil wars.

Subsequent to a review of the keywords approach and a section on methods, this paper examines the cases of Darfur, Colombia and Yemen. The Discussion section then describes four broad patterns that emerge in keywords across the cases (Table 1), outlines their utility and proposes future research questions.

\section{Theoretical Background}

The concept of a 'keyword' as initiated in Williams' (1985) work involves, not an index or target word or a way of retrieving documents or information as is commonly applied, but instead a word that is socially prominent and that bears a cluster of interlocking but often contradictory contemporary meanings that are an integral and active part of the problems they describe. In this concept, interaction between meanings (common as well as technical meanings) remains unresolved across an array of issues, peoples, histories, grievances, politics, narratives, livelihoods, institutions, and importantly, laws. Such unresolved interaction between different understandings results in confusion, controversy and cross purposes, as well as contestation and confrontation in public and personal debate (KP, 2013).

There are two primary, although related ways such variation in meaning (confusion) emerges. The first results from the non-uniform, or patchy nature of historical change in the meaning of 
important terms. This comes about because change in meanings do not occur everywhere over the same period of time at the same rate for a particular society. As a result some of a word's earlier meanings remain in current usage in the present--along with the beliefs and values of the earlier meanings (KP, 2013).

The second type of confusion arises through polysemy--or concurrent, multiple meanings which are semantically and historically related--something akin to an evolutionary tree. In this type the different concurrent meanings are amenable to different directions of development, valorisation or promotions--positive, negative, identity enhancing, victimization, etc.--depending on the beliefs and attitudes of the user. This can occur either by purposefully promoting a certain interpretation or narrative as a form of ideological or political advocacy (KP, 2013), or it can develop over time as people attached to one understanding or another become increasingly embedded in separate and increasingly isolated information networks which leads to their occupying different interpretive worlds. Toal and Dahlman (2011:84) describe for the Bosnia conflict how such embedding was an, "extremely significant force facilitating the division of Bosnia". Similarly Malkki (1995) writing about the Burundi and Rwanda conflicts, notes that different interpretations can become reinforced, as events, relations and processes regarding certain issues come to be construed along specific lines. Thus as social relations become more divisive in the period prior to armed conflict, specific constituencies increasingly talk only to themselves, so that information and communication networks become isolated from each other, thereby encouraging greater divergence in multiple meanings (also Unruh and Abdul-Jalil, 2014).

Fundamental to Williams' (1985) concept of keywords is that they emerge from and are used in important contemporary political and social debate. Williams' analysis of keywords used the philological history of such words as a way to examine their contradictory current meanings and uses. Thus the different meanings of keywords reflects the historical contours of a particular political and social debate and the status of its present arguments--becoming quite complex where different local languages are involved. For Williams (1985) the contested meanings of keywords are inextricably bound up in the societal problems that they are used to discuss, with certain usages binding together specific ways of seeing culture and society. Thus keyword analysis is not simply about semantics. Because keywords are fused with and inseparable from the problems they represent, they contribute to the development of the problems and as a result they can be used to elucidate what the nuanced contours of the fundamental problems of certain societal issues are. Highlighting the interconnectedness of keywords with the problems and contestations conducted by their use, is Williams' (1985) opinion that clarifying the confusions and variations of meaning would have little value in resolving the actual conflicts themselves. Indeed the conflicts and problems cannot be resolved by reducing the complexity of keyword usage, because the difficulty is not ultimately in the keywords, but in the problems which are reflected in the variations of keyword use (Williams, 1985). However there is ample evidence of the power of words and history in the development of armed conflicts (e.g., Makdisi and Silverstein, 2006).

While civil war is certainly a national social debate in its most acute form, actual combat has less to do with the nuances of the debate than it does with the near-term objectives involved in armed encounter. However the critical social debates are nevertheless robustly pursued by the 
populations that support the various sides in a conflict, and such debates by the broader population well precede the onset of armed conflict (Unruh and Abul-Jalil, 2014). As a result the keywords that are most operable in a conflict context were likely visible and apparent well before the conflict.

Work subsequent to Williams (1985) outlined five criteria that distinguish keywords (KP, 2013). Keywords typically are:

1) Currently used, in that they have both a common, and a technical use. Thus a keyword is used to both negotiate and express meanings in daily discourse, but also to lay claim to a form of authority based on one or more discipline-based or technical uses; with the combination contributing to its confusion and complexity.

2) Polysemous, or manifesting different meanings when used on different occasions, and by different groups, such that use of any one meaning excludes other possible meanings.

3) Categorical, in that they seem to denominate social (including cultural) practices and concepts. As a result they tend to be highly influential in society at large and particularly in social debates because they provide, "recognized verbal identity to, or 'lexicalise', social practices, beliefs, value systems, and preferences" (KP, 2013).

4) Actively contested, such that they play an influential role in a social debate, dispute or conflict. Such debates and conflicts differ from those that exist solely within academic, professional or technical arenas in that they also involve the population at-large in viewpoints and arguments regarding the direction of society. Such keywords would be involved in what political leaders call a 'national debate'.

5) Part of a cluster of interconnected terms which co-occur. In other words a keyword operates as a part of a set of words which together are the vocabulary of debate for a specific topic or issue.

\section{Methods}

The overall objective of this article is to test the utility of the keywords approach to examine how important land rights terms, concepts and meanings come to be interpreted, used and aligned with segments of society who become opposed in civil wars. Thus the cases below identify the keywords and describe their history, different meanings and uses, their roles in the development of armed conflict; and importantly how they came to have multiple, contested, confusing and ambiguous interpretations. The discussion then looks at patterns that have emerged from the cases (Table 1) ${ }^{2}$ and presents further questions relevant to the potential applied nature of keywords in peace-building.

A comparative case study approach is used by looking at three different armed conflicts. The cases selected reflect two criteria. First, they are drawn from significantly different geographic, cultural, historical and linguistic circumstances. Thus cases are drawn from Latin America, Africa, and the Middle East and represent situations where the countries are both recovering from war (Colombia) and where armed conflict is still underway (Yemen, Darfur). Second, indepth knowledge of the cases is needed in order to examine the interfusion between the problems and the keywords. Fieldwork was carried out in Darfur in 2009 and involved key infor-

${ }^{2}$ While three cases are presented in the paper, the initial study involved six, and these are presented in the Table. 
mant and focus group interviews totaling 196 people. The topics covered included a wide variety of issues relating to the history of land rights and the conflict. In Colombia fieldwork was undertaken in 2007 and 2011 as part of the government's efforts to address the land rights and dislocation aspects of the war and involved 164 people in focus groups. In Yemen fieldwork was conducted in 2013 and 2014 and involved 580 people covering topics relating to the history of land rights and restitution. The author conducted interviews and engaged in participant observation in all cases. The field research is complemented by an analysis of the relevant literature on the specific cases, and the literature on keywords and the uses of language in war.

In the cases that follow, keywords were arrived at through the application of two questions in reviewing each case. First, what land rights-related terms are central to the most acute, volatile land dilemma(s) in the war. And second, are these terms used differently by the different sides in the war thus revealing discontinuity in meaning. Once the terms were identified, they were then traced back into the period prior to the war, in order to chart their development. The cases are then examined with a particular focus on three dimensions--groups, institutions (including law) and history (Table 1), in order to describe how keywords emerge and evolve over time.

A clarifying note about the 'confusion' aspect of keywords. As the cases elaborate, the confusion over keywords that is operative at the onset of armed conflict is about much more than simply the various groups in the conflict misunderstanding each other. It is this, however it is also a marker for the historical and institutional trajectories of the groups in question with regard to each other, that has misunderstanding emerging as a secondary effect. As noted above, this marker is valuable for spotting keywords both prior to, and during armed conflict.

\section{Darfur}

\section{The Cases}

\section{Background}

The war in Darfur began in 2003 when rebel groups aligned with the agriculturalist population moved militarily against the Sudanese government, which they accused of oppression, neglect and discrimination. The government responded by recruiting the Janjaweed and moving against both rebel militias and the civilian population. Land rights are at the heart of the war, and for the different groups involved in the conflict are complex, confused, sensitive, and volatile (Flint and De Waal, 2008; DDPD, 2011; Suiliman, 2011). In one of the most acute manifestations of the land rights problem, certain Arab pastoralists were easily recruited into the Janjaweed for two primary reasons, land and money (Flint, 2009).

During the pre-colonial sultanate period the sedentary agriculturalist tribes acquired for themselves or were granted, a large territory of land that became their homeland (Dar). The term 'Dar Fur' then connotes the homeland of the Fur tribe, with the broader Darfur area now encompassing a number of tribal Dars which were subsequently recognized by the colonial and independence governments. The land tenure system operating within the Dars functions off of a framework of sultanate era land grants or 'hakura'. Thus the hakura tenure system based on sedentary agriculture became the prevailing customary system over most of contemporary Darfur (O’Fahey and Abu Salim, 2003). 
While agriculturalists occupying most of central and southern Darfur have their own Dars, the Arab camel nomads of North and West Darfur do not. This is partially due to the fact that the granting of tribal Dars during the Sultanate era favoured larger tribes, but as well because in the past permanent forms of land claim were not important for nomadic pastoralists, who depended instead on transient rights of access. Thus the various tribes of Darfur can be classified into land-holding (hakura practicing) and non-land-holding groups, with the alignment of different groups in the war falling out along this distinction (Unruh and Abdul-Jalil, 2014). From their perspective, Arab pastoralists of northern Darfur saw an opportunity in the war to correct a long-standing injustice of landlessness caused by the sultanate, customary, colonial and independence legal land regimes, by pursuing their acutely felt need for land and hence greater political participation in Darfur. At the same time sedentary agriculturalists were (and continue to be) threatened by the increasing numbers of pastoralists and other outsiders who are able to gain access to their lands via statutory and Islamic law in an increasingly aggressive and confrontational way (Unruh, 2012). This pattern of land relationship constitutes one of the fundamental ingredients of the current civil war because control over land and political participation (hence power) are inseparable in Darfur.

\section{$\underline{\text { Keywords }}$}

The primary keyword in this case is the term 'hakura'. While 'access', 'homeland' and 'tribal land' are the other words in the cluster, for the sake of brevity the focus here is on hakura. The term is pervasively used with regard to the customary tenure system in Darfur, but in a variety of ways. In some cases hakura as a spatial unit is referred to as a subset of a Dar and given to a specific person, in other cases hakura is taken to mean the same area as a Dar. For some, hakura is an institution or a system of institutions (and not a specific land area) that should be variously reinstated, expanded, ignored, done away with, or outlawed, depending on the group (factions, constituencies, government, ethnic groups). Still others take hakura to mean a form of ownership rights, while some refer to hakura as simply the sultanate era document itself attesting to the granting of land. In addition, information about many of the hakura (as landholdings) exist as broad narratives which emerged well before the current conflict. These narratives can be subjective and contradictory, particularly regarding how many hakura there are, where they are, and what the boundaries are (Egemi, 2009). The role of these prewar hakura narratives as a basis for land rights became more important as the conflict progressed, given that many hakura documents have been purposefully destroyed in the war. Thus the Arab pastoralists of the north justify their participation in the current conflict as part of a 250 year-old quest for land that was provided to others but denied to them. This perspective, while not well aligned with actual history, is so acute that "hakura has become a battle-cry of the Janjaweed" (O'Fahey, 2008:136).

In Darfur there are different 'positions' on the multiple meanings of hakura. For example when hakura is taken to mean a set of institutions (rule sets), the sedentary agriculturalists (aligned with the rebels) consider these to be of long-standing legitimacy and part of a larger cultural narrative that is under threat, such that the institutions need to be more strongly applied and enforced. For the Arab pastoralists (aligned with the Janjaweed/government), such institutions are simply rules that should be subject to change to reflect the new reality, particularly as they are seen to be highly discriminatory. When hakura is taken to mean a historical document attesting to land rights, the agriculturalists see the document as attached to and a component of a 
legitimizing historical and cultural narrative. Whereas the pastoralists see the destruction of such documents as a lack of proof of land rights.

Meanwhile statutory law is also conflicted regarding hakura. In particular there is confusion and contradiction with regard to the tenurial concepts and definitions of hakura, tribal land, private property, Dar, and the property versus administrative nature of statutory vs. hakura boundaries (Unruh and Abdul-Jalil, 2014). The Unregistered Land Act of 1970 (ULA) was particularly problematic. The law specified that all land not registered before the Act via the Land Settlement and Registration Act of 1925, became government land (Unruh, 2012).

There is also ambiguity and multiple interpretations of Islamic law with regard to hakura. Islamic law is fused with customary law in Darfur, as it is in much of the Muslim world (e.g. Sait and Lim, 2006). The historical land documents granting hakura to their original holders in the sultanate era refer to Allah, the Qur'an, Islamic law, and Islamic precepts throughout (O'Fahey and Abu Salim, 2003). Some of the hakura documents (also referred to as deeds or charters) were actual waqf ${ }^{3}$-granting documents, while others were 'waqf-like' to varying degrees in that they were given to religious figures and were intended to be continuously held by their descendants; and still other hakura were charters of privilege granted to various holy clans (O'Fahey and Abu Salim, 2003). As a result, a particular hakura deed with a significant amount of, or more powerful religious phrasing, would be considered more waqf-like than others, and hence a stronger form of landholding. However the Arab pastoralists sought to discount the establishment of such waqf-likeness in the hakura documents and hence the Islamic legal strength of the land claim by supporting the targeting and destruction of the hakura deeds by the Janjaweed in an attempt to reduce the customary legal basis for hakura claims. As O'Fahey $(2008,136)$ notes, referring to these documents, "today they are weapons of war". The Arab pastoralists and the Sudanese government also invoke different uses of Islamic law in order to access hakura lands. Beginning with the phrase, 'all land belongs to Allah', the government follows this with an interpretation that allows the state to be the trustee of lands with the power of allocation. For the pastoralists however, the phrase is followed by, 'and is therefore open to any Muslim'. Thus the different interpretations of Islamic law are used to justify claims to hakura land in different ways to separate sets of people.

Thus for Darfur, the keyword, 'hakura' intersects with groups (pastoralists, agriculturalists, and then the Janjaweed, rebel groups and government forces) through institutions (customary law, statutory law, Islamic law), over several periods in history (sultanate, colonial, independence eras and the current conflict) to become an important, conflicted keyword embodying multiple meanings.

\section{Colombia}

Background

Beginning in the mid 1960s with the FARC ${ }^{4}$ seizing large landholdings and redistributing it to those who labored on it, the conflict in Colombia developed over the decades to also include

\footnotetext{
${ }^{3}$ A waqf is an Islamic law religious endowment of land or property, and is generally considered to be inalienable.

4 The Fuerzas Armadas Revolucionarias de Colombia (FARC) is the primary rebel guerrilla group.
} 
right wing paramilitaries, narco-traffickers, the Colombian national forces and peasant group and large-scale commercial interests in land and territorial control (GMH, 2010; Posada, 2009). At the onset of the conflict, grievances generated by the takeover of peasant lands by more powerful interests led to the insurgents kidnapping large-farm owners, which led many of the latter to depart the area; selling their haciendas very cheaply to narco-traffickers and others who would then establish a paramilitary presence in the area. Once the area was secured the land would be sold on at a much higher price. Thus the escalation of the war and the rise of land speculation based on the war, was a parallel process (Posada, 2009).

When peace talks began in 2012 between the FARC insurgency and the Colombian government in an attempt to resolve the nearly 50 year civil war, land rights and rural development was the first item on the agenda. Thus while resolving the land issue is a precondition for ending the war, land conflicts can only be resolved if the violence stops (Economist, 2012); with the larger agrarian problem being both a cause and consequence of the war (Sanchez, 2010).

\section{Keywords}

For the Colombian conflict the primary keyword is 'occupation', which resides at the center of a cluster of words that include, 'abandoned', 'indigenous', and 'displacement'. Occupation has a number of different meanings with regard to the conflict in Colombia, and these were used as effective tools in the war and in gaining land access to the advantage of one group versus another prior to the war. Earlier in Colombia's history when the frontier was still open, 'occupation' meant a process of colonization that displaced indigenous populations (Posada, 2009). Subsequently, boundaries were established between indigenous areas and lands open to settlement, stipulating which areas could be occupied by settlement and large farms, versus occupation by indigenous groups. However the eventual mixture of indigenous, Spanish, and African blood made the boundary distinction between indigenous land and the areas where large farms were allowed, inoperable in significant parts of the country. This allowed for 'occupation' and hence claims on former indigenous lands by large-farm settlers. However the perception of those who believed themselves to be indigenous, or a mix of indigenous and other, was based on their 'occupation' of indigenous land according to the distinction between the indigenous and non-indigenous areas (Posada, 2009). This led to a considerable number of very volatile land disputes. As time went on, land possession by those that believed themselves to be indigenous enough to claim such a form of 'occupation', could not be extended over large areas as they could when the indigenous - non-indigenous boundaries were widely respected. As a result smallholder farms became the norm under such indigenous forms of occupation (Posada, 2009).

With Law 200 of 1936, rights to property acquired by prescription (occupation) was recognized. Such occupation generated use rights for 20 years. The law was intended to favour the peasant small-scale landholder (campesino), but was also used by large-scale land interests who put their own campesinos on the land to 'occupy' it. These campesinos then sold the land to the large-holders. In this way the large-scale land interests took over significant areas of the country. Toward the end of the 20th century, the agrarian conflicts over this inequity led to direct invasion and 'occupation' of cattle ranches by campesinos, dislocatees, and those that perceived themselves to be indigenous. This development was legitimized by the agrarian reform as pursued by President Restepo (1966-70) who affirmed that if large-scale landowners op- 
posed the redistribution of land, campesinos should 'occupy' the haciendas in order to force agrarian reform (Posada, 2009). Thus in this meaning, 'occupation' became a policy of agrarian reform. The reform program included an alliance with the campesino in order to achieve it, and the resulting Asociación Nacional de Usarios Campesinos (ANUC) subsequently transformed into a vast social movement of more than a million people who invaded and 'occupied' about 2000 haciendas between 1971 and 1975 (Posada, 2009). In this sense 'occupation' meant invasion and reclaiming lands. The subsequent deactivation of the agrarian reform then contributed to the radicalization of the campesino, who continued the now illegal occupation of large farms, which then contributed to the insurgency (Posada, 2009).

During the conflict rebel forces played an important role in the different perceptions, uses and development of 'occupation'. In some regions the guerrilla aligned itself to local conflicts and grievances against the state, and supported campesino invasions and occupations of haciendas. In other regions however as the war progressed, the guerrilla were paid by the owners of haciendas for protection from invasion and occupation by campesinos (Posada, 2009). As a result the landless campesino in the latter areas abandoned its ties and loyalty to the FARC (Posada, 2009). In this regard the FARC contributed to both processes of keyword development noted previously--the patchy nature of change in the meaning of important terms, and polysemy.

Thus for Colombia, 'occupation' intersected with groups (indigenous, campesino, ANUC, large-scale landowners, government and then FARC and government troops) through institutions (legal categories of indigenous and settler, Law 200, agrarian reform and then the legislation deactivating it) through history (the open frontier period; the distinction between and then the mixing of indigenous, Spanish, and African blood; the development of smallholder farms; the period of agrarian reform; post reform; and then the period of armed conflict) to produce a highly contested and volatile term.

\section{Yemen}

Background

Land related conflicts, grievances and confusion are a primary component of the current instability in Yemen ${ }^{5}$ and resonate strongly in the current Houthi conflict, the Southern secession conflict, and al-Qaeda activities (al-Fadhli, 2012). Subsequent to the unification of northern and southern Yemen in 1990 the Saleh regime's drive to control land resources in the south was one of the primary reasons the country fell into civil war in 1994 (Day, 2012). Currently, the proportion of cases in the primary courts that concern land and associated water resources is estimated to be between 50 and 80 percent of all cases (YAVA, 2010). Land played a primary role in the patronage system of the Saleh government prior to its demise in 2012. Land confiscations and reallocation in order to punish some groups and individuals and reward others were commonplace in the Saleh regime, and were important in propping up the government for the 30 plus years it was in power. While there are currently three insurgent campaigns in Yemen--the Houthi rebellion in the north, al-Qaeda in the Arabian Peninsula (AQAP) in the

\footnotetext{
5 In Yemen land is held within tribes and then families. A tribe is commonly understood to be indivisible from its land and often the names of a tribe and a place are the same or synonymous (al-Fadhli, 2012).
} 
south and east, and the secessionist al-Hirak movement in the south--the keywords case presented here deals with the latter conflict, although AQAP is involved.

The 1994 war which erupted due to discontent in the south over unequal relations with the north, and the north's victory led to two scenarios which significantly aggrieved the southern population. These were the dismissal of southerners from the country's military and civil services, and a two decade surge of land expropriations in the south by northern political, economic and military elites and their associates that continues today (Hill, et al 2013). The ongoing land issues in the south are a primary cause of the current secessionist movement and an opportunity for the involvement of al-Qaeda in the the southern governates (van Veen, 2014). Land grabs, tribal connections with lands, corruption, confiscations, the lack of rule of law and multiple claims, combine to make land rights issues a central feature of the current discontent and instability in the south (e.g., YAVA, 2010; Salisbury, 2013; Schechla, 2013). Addressing land confiscations and restitution in the south is a priority within the post Arab Spring National Dialouge in Yemen, ${ }^{6}$ and are one of two lead issues the government in Sanna, the Gulf Cooperation Council, and the UN are, at the time of writing, pursuing in an attempt to bring stability to the south (PD, 2013).

\section{Keywords}

The primary keyword here is 'sultanate land', with this connected to a cluster of words that also label land, 'state land', 'private land', and 'tenant land'. These terms have confused, ambiguous and overlapping meanings and usually involve the same lands. An important historical development involving sultanate lands occurred when the socialist regime of then South Yemen abolished the sultanates in 1967 and declared all lands to be 'state land' (Day, 2012). Many sultans and sheiks fled to Saudi Arabia during this time, and others not native to the sultanates then moved onto the former sultanate land to use it as 'tenant land' renting from the state (Kambeck, 2014; FW1, 2014). At some point tenants decided they were in a position to sell land on to others as 'private land'. And in many cases the tenants were approached by outsiders who encouraged such sales. In addition, large portions of former sultanate lands were seized by powerful political and military interests in their status as 'state land'. At unification, president Saleh brought back the sultans and associated sheiks and gave them their land back. In gratitude the sultans gave the president approximately 20 percent of their lands, as they knew he would confiscate it anyway. However there is confusion over whether land given to Saleh became 'private land' or 'state land' (Kambeck, 2014), and with Saleh gone if such lands should now be returned as 'sultanate land'.

Upon their return the sultans demanded their land back from those who had purchased or confiscated it during the intervening years or were using it as tenant famers--thus attempting to convert 'private land' and 'tenant land' back to 'sultanate land'. Many of these cases ended up in court. However the courts in Yemen are corrupt and unable to resolve such cases, which in the present context encourages the sultans, sheiks and their kin to approach al-Qaeda to assist in retaking lands from private and tenant holders $(\mathrm{FW} 1,2014)$. This is facilitated by the fact that a number of the returning sheiks fought with bin Laden in Afghanistan and so already had im-

6 The National Dialogue is a transitional process and part of the Gulf Cooperation Council Initiative (and United Nations Security Council Resolution 2051). 
portant connections to al-Qaeda (FW1, 2014). Al-Qaeda in the Arabian Peninsula explicitly supports the southern secessionist movement (al-Hirak) in their bid to make southern Yemen a separate country (Day, 2012).

An additional complication regarding 'sultanate land' was the appointment of many sheiks by the Saleh government and the establishment of a land role in the position of sheik. Prior to the departure of the sheiks at the onset of the socialist era, they had no land allocation role within the sultanates. However in order to engage in divisive and patronage politics, the Saleh regime gave the sheiks a land function, and also increased their number dramatically, appointing sheiks that were beholden to the regime. For example in 1958 the Fadhli sultanate had 13 sheikhs. But through appointment the sultanate now has about 2800 (al-Fadhli, 2012). Thus in the patronage system of the Saleh era, the government would provide certain sheiks with control over large amounts of 'sultanate land' to then be divided up as 'private land' among those individuals and groups the sheiks were connected with in order to keep them compliant with the regime, and facilitate the sheiks' own patronage system. This process usually relieved the previous occupants (indigenous, tenant and private landholders) of their land and created numerous volatile land disputes that to this day go unresolved. While the Saleh regime is gone, the sheiks continue with this land allocation role even as former occupants try to get their land back. These allocations are not coordinated with local and governate land offices or other state authorities or the National Dialogue process, such that there is ongoing confusion about what land should be labeled, and what land belongs to who and is used by and claimed by who. Adding to this confusion, under the Saleh regime, if a sheik who was provided with control over land fell out of favour with the regime, the government would take the land back, ignoring the fact that it had already been divided up and allocated to others as 'private land'. Appointed sheiks who continue to use their sultanate affiliations to reallocate land into private holdings which are then sold on, add particular confusion and animosity to the overall land rights situation currently.

Ambiguity over sultanate land and the actions of appointed sheiks, was a primary tool used by those from the north to seize, purchase and swindle southern lands from 1990 to present. Today the restitution of these lands back to their original owners is an important part of the National Dialouge (Salisbury, 2013). But with large segments of the southern Yemeni population significantly aggrieved over the issue, they see secession as the only way forward, thus providing significant fuel to the al-Hirak separatist movement (Salisbury, 2013).

Thus there is a good deal of confusion over the current standing of 'sultanate land' and whether this land is instead 'private', 'tenant', or 'state land', or if the latter three effectively extracted land from what was historically 'sultanate land'. This confusion and ambiguity interacts with the country's many internal divisions to produce multiple competing contemporary meanings of 'sultanate land', as well as competing narratives regarding what happened to which lands and to who and when in land rights scenarios (Day, 2012). Day $(2012,157)$ in examining this period in Yemen's history, notes that, "[i]ntergroup resource competition is one of the main factors that hardens group identities in opposition to outsiders". 
For the Yemen case the term, 'sultanate land' used by specific groups (southerners, northerners, tribes, al-Hirak, al-Qaeda, sheiks and sultans, tenants, holders of private land, government) through institutions (the National Dialouge's land restitution program, the sultanate system, patronage systems, local government, legislation abolishing then re-establishing the sultanates) over specific periods of history (the socialist era in southern Yemen, the departure of the sultans, the unification period under Saleh and the return of the sultans, the 1994 war and its aftermath, the current post-Arab Spring period) contributes to a significant and ongoing instability in the present.

\section{Discussion}

This article has attempted to explore the utility of the keywords approach in examining the historical, socio-spatial contours of land rights in three different civil wars. While certain patterns do emerge, significant questions for further research that may bring greater utility to these patterns also emerge. From the brief examination of the keywords in the cases presented, four patterns appear important. First, while the different meanings of the various keywords became aligned with different sides in their respective conflicts, because the meanings developed and became divisive prior to the war in question, they also appear to have contributed to defining what the different sides in the various wars were (Table 1). Thus as keyword meaning developed, diverged, and became increasingly controversial and confrontational in the period prior to conflict, the different meanings helped define who was at fault, victimized, taken advantage of, gained and lost, and unjustly favoured or disfavoured with regard to land rights. This significantly contributes to who is opposed to who in a conflict and how and why. An important question in this regard is, might such insights have utility to those in the international community needing an in-depth understanding of a conflict and the history which led to it, in order to more effectively engage in the different aspects of peace-building--mediation, peace accord negotiations, land and property restitution efforts, legal reform, reintegration, etc? And could such insights be quickly acquired using a rapid assessment method devised to ascertain relevant keywords in a conflict? A limitation to such utility may be that it can take time to examine a conflict and its history in the detail necessary. However this is connected to knowing what to look for, such that a defined, stepwise procedure (the construction of which is beyond the scope of this paper) might make spotting keywords fairly rapid.

Second, the keywords and the problems they embody all appear to involve law in a significant way (Table 1). For the Darfur case, law played a large role through application of hakura customary law, along with colonial and national statutory legal land regimes and interpretations of Islamic law. For Colombia, the laws important to keyword development included a law creating boundaries between indigenous areas and lands open to settlement, along with Law 200 of 1936 which delineated rights to property acquired by occupation, and the legislation involved in the agrarian reform of 1966-1970 and then laws deactivating it. In Yemen, first the socialist era laws of southern Yemen which dismissed the sultans and sheiks from their land and claimed all land for the state, and then the subsequent unification era laws that brought back the sultans and sheiks and provided appointed sheiks with a land allocation role, contributed to the ambiguity and grievance over land in the south. As well the statutory laws that labeled land as 'state land', 'private land' and 'tenant land', overlain on 'sultanate land', added to the confusion; as did the use of Islamic law as part of statutory and customary law. 
Given the role of law in the development of keywords (and the issues and processes they reflect and are a part of) towards conflict, the question that emerges is, can new or altered laws, or different uses of law, also play a role in continuing this development, but in directions more conducive to peace-building? Here it is argued, when keywords are either used in law (or the reverse) or are created or encouraged by law (statutory, customary, religious), the constraints and opportunities created can have a significant role in the development and direction of the actual problems themselves, either toward their exacerbation or diminution. This occurs not only by enforcing laws, but how people use laws to justify actions, including in the context of law as discourse (Bruner, 1991). Thus understanding how the keywords - problem interfusion develops, and how this development is connected to law, can provide the opportunity to engage this connection purposefully, thus 'pushing' the interfusion in certain directions.

A third pattern that emerges is that keywords can be used as a form of 'tool' to varying degrees in the conflicts themselves (Table 1). While the use of hakura "as a weapon of war" (O'Fahey, 2008, 136) is explicit in the Darfur case, other cases manifest similar uses of land-related keywords. In Colombia certainly 'occupation' was used prior to and during the war to take over land belonging to large-holders by campesinos and their guerrilla backers at different points in time. And in Yemen invoking particular meanings of 'sultanate land' was a tool in attempts to regain land. Certainly various local political actors seeking support from particular constituencies during wartime are very adept at using keywords as tools to incite, motivate and instigate. But can peace-building efforts likewise use keywords as effective tools to push the narratives in which they are embedded in certain directions? Unruh and Abdul-Jalil (2014) provide an example of this possibility for Darfur. One possible limitation to using keywords in peace-building is that the UN and other actors in the international community prefer discrete, specific peace-building projects with specific, easily measured outcomes. Seeking to 'push' keywords in certain directions would have non-specific, more ambiguous and difficult to measure outcomes.

A fourth pattern, or set of patterns, involves the ways that the keywords themselves can be examined and categorized. It is interesting that for the 20 keywords looked at in the three cases, they do not repeat. This perhaps attests to the importance of individual country history in the development of keywords. The keywords examined also appear to fall into two broad functional categories--'actions', and 'labels' (Table 1). Action keywords, such as 'transfer', 'occupation', 'displacement' and 'exclusion', when repeated frequently (as actions) can become processes (or a series of events) by which individuals and groups can take or be relieved of land and property that in aggregate then covers quite large areas. The contest can be over how, and that, these actions take place, and what they are used for--expropriation, ethnic cleansing, etc. Label keywords, such as 'sultanate land', 'private land', 'tribal land' and 'homeland', are identifying or descriptive markers attached to specific lands covering large areas. The contest appears to be over either which label is used by who and when (and the implication for rights), such as sultanate land, private land or tenant land; or, about the definition of the label itself--'adequate area', 'hakura', 'essential'. A related pattern is that for each case the central keyword and its cluster are essentially all either action or label keywords, and not a mix. Hence Yemen is a 'label' case--'sultanate land', 'state land', 'private land', and 'tenant land'. Colombia is an action case--'occupation', 'abandoned', 'displacement'. Darfur is a label case--'hakura', 'homeland', 'tribal land'. 
It is also worthwhile to note that these two categories of keywords appear to operate at different scales. Action keywords operate more at an individual level--specific smaller-scale lands attached to certain people that are transferred, settled, occupied or abandoned in a repeated series of individual events. Label keywords operate at a larger scale, often involving the state and the labels the state or large groups try to attach (via law) to certain large areas containing and/or being made accessible by many people. With this fourth set of patterns in mind, one future research question is, given the 'label' vs 'action' nature of the keyword clusters (and the problems they represent), what does this mean for how certain components of a peace process might intersect with the 'label' vs 'action' cases? Such components would include restitution of land and property and the various methods and remedies for doing this; return and reintegration; compensation for lost land; land policy reform; etc.

\section{Conclusion}

As contemporary conflicts move increasingly from interstate to intrastate wars, the need for effective tools for use by the international peace-building community becomes acute. In this regard greater attention needs to be placed on the technical analysis of how civil conflicts develop at the level of discrete populations within societies. This article is a first attempt to investigate the utility of the keyword approach to understanding the development of land rightsrelated armed conflicts. While further questions remain, the approach would appear to hold potential.

\section{Bibliography}

Abdul-Jalil Musa, A. (2006). The dynamics of customary land tenure and natural resource management in Darfur. Land Reform, Settlement and Cooperatives, 2, 9-23.

Alden-Wily, L. (2008). Commons and conflict states: Why the ownership of the commons matters in making and keeping peace, Washington DC: Rights and Resources Initiative.

al-Fadhli, H.A. (2012). Presentation to the office of the UN Special Representative, Sanna, Yemen.

Bennet, T., Grossberg, L., Morris, M. (eds.) (2005). New keywords: A revised vocabulary of culture and society. Oxford, UK: Blackwell.

Brooker, P. (2011). Modernism under review: Raymond William's the politics of modernism. Modernist Cultures 6, 201-214

Bruner, J. (1991) The narrative construction of reality. Critical Inquiry 18, 1-21.

Crowley, T. (2012). Scouse: A social and cultural history. Liverpool, UK: Liverpool University Press. 
Dahlman, C. (2005). Geographies of genocide and ethnic cleansing: The lessons of BosniaHerzegovina. In C. Flint (Ed), The geography of war and peacekeeping: From death camps to diplomats. Oxford, UK: Oxford University Press.

Day. S, (2012). Regionalism and rebellion in Yemen: A troubled nation. New York: Cambridge University Press.

Draft Darfur Peace Document (DDPD) (2011). Draft Darfur peace document. Doha, Qatar.

Durant, A. (2008). The significance is in the selection: identifying contemporary keywords. Cultural Quarterly 50, 122-142.

Economist, The (2012). Land reform in Colombia: peace, land and bread. The Economist, Nov 24.

Egemi, O. (2009). Land tenure issues in Darfur. Nairobi: UN Habitat.

Field Work 1 (FW1) (2014). Author's fieldwork in Yemen.

Flint, J. (2009). Beyond 'Janjaweed': Understanding the militias of Darfur. Small Arms Survey.

Flint, F., \& De Waal, A. (2008). Darfur: A New History of a Long War. London: Zed Books.

Grupo de Memoria Historica (GMH) (2010) La tierra en disputa. Bogota, Taurus.

Hales, G. (2009). Small Arms Survey researcher. Cambridge, UK: Cambridge University Press.

Hill, G., Salisbury, P., Northedge, L., Kinninmont, J. (2013). Yemen: corruption, capital flight and global drivers of conflict. A Chatham House Report, September.

Home, R. (2003). An `irreversible conquest'? Colonial and postcolonial land law in Israel/Palestine. Social and Legal Studies, 12, 291-310.

Jensen, D., Crawford, A., Whitten, P., Bruch, C., Harris, A., Brown, G. (2013). Policy brief: land and postconflict peacebuilding. Washingington DC: Environmental Law Institute.

Jones, P., \& Holmes, D. (2011). Key concepts in media and communication. London: Sage.

Kambeck, J. (2014). Land disputes in Yemen. In H. Lackner (Ed.), Why Yemen matters: A society in transition. London: Middle East Institute at SOAS.

Makdisi, U., \& Silverstein, P. (2006). Memory and violence in the Middle East and North Africa. Bloomington: Indiana University Press. 
Malkki, L. (1995). Purity and exile: Violence, memory, and national cosmology among Hutu refugees in Tanzania. Chicago: University of Chicago Press.

Mitchell, D., \& Breitbach, C. (2006). Raymond Williams. In P. Hubbard, R. Kitchin, G. Valentine (Eds.), Key thinkers on space and place. London: Sage.

O'Fahey, R., \& Abu Salim, M. (2003). Land in Dar Fur: Charters and related documents from the Dar Fur Sultanate. Cambridge: Cambridge University Press.

O’Fahey, R. (2008). The Darfur Sultanate: A history. New York: Columbia University Press.

Posada, A. (2009). Guerreros y campesinos: El despojo de la tierra en Colombia. Bogota: Groupo Editorial Norma.

Presidential Decree (PD) (2013). Issuance of a presidential decree establishing two commissions to address the land issues and the government employees forced out of their jobs in the southern governorates. Presidential Decree no. 2 for 2013, Sana'a, Yemen: Office of the President.

Keywords Project (KP) (2013) What is a keyword? University of Pittsburg. Retrieved on October 312014 from http://keywords.pitt.edu/whatis.html.

Raymond Williams Society (RWS) (2013) The Raymond Williams Society. Retrived November 2, 2014 from www.raymondwilliams.co.uk.

Sait, S., \& Lim, H. (2006). Land, law, and Islam: Property and human rights in the Muslim world. London: Zed Books.

Salisbury, P. (2013). Yemen's southern intifada. Retrieved October 28, 2014 from http://mideastafrica.foreignpolicy.com/posts/2013/03/13/yemen_s_southern_intifada.

Sanchez, G. (2010). La tierra en disputa: Memorias de despojo y resistencia campesina en la costa Caribe (1960-2010). Bogota: Grupo de Memoria Historica.

Schechla, J. (2013). Lands of the Arab spring. Digital Development Debates, Issue 10. Retrieved November 9, 2014 from http://www.digital-development-debates.org/issue-10-hunger-for-resources--lands-of-the-arab-spring.html.

Suleiman, Y. (2004). A war of words: Language and conflict in the Middle East. Cambridge, UK; Cambridge University Press.

Suiliman, O. (2011). The Darfur conflict: Geography or institutions? New York: Routledge Press.

Toal, G., \& Dahlman, C. (2011). Bosnia remade: Ethnic cleansing and its reversal. Oxford, UK: Oxford University Press. 
Unruh, J.D. (2012). Land and legality in the Darfur conflict. African Security, 5, 105-128.

Unruh, J. \& Williams, R. (2013). Land and post-conflict peacebuilding. New York: Earthscan.

Unruh, J.D. \& Abdul-Jalil, M.A. (2014). Constituencies of conflict and opportunity: land rights, narratives and collective action in Darfur. Political Geography, 42, 104-115.

van Veen, E. (2014). From the struggle for citizenship to the fragmentation of justice: Yemen from 1900 to 2013. The Hauge: The Clingendael Institute, Conflict Research Unit.

Wierzbicka, A. (1997). Understanding cultures through their key words. Oxford: Oxford University Press.

Williams, R. (1985). Keywords: A vocabulary of culture and society. Revised Edition. Oxford, UK: Oxford University Press.

Yemen armed violence assessment (YAVA) (2010). Under pressure: social violence over land and water in Yemen. Small Arms Survey, No. 2, October. 
Table 1. Primary elements of cases included in the initial study

\begin{tabular}{|c|c|c|c|c|c|}
\hline $\begin{array}{l}\text { Patterns } \\
\text { Cases }\end{array}$ & $\begin{array}{l}\text { Primary } \\
\text { actors in } \\
\text { the conflict }\end{array}$ & Keywords & Law & $\begin{array}{l}\text { Keywords } \\
\text { as tool in } \\
\text { war }\end{array}$ & $\begin{array}{l}\text { Keyword } \\
\text { type }\end{array}$ \\
\hline Darfur & $\begin{array}{l}\text { Govt. \& Jan- } \\
\text { jaweed mili- } \\
\text { tias vs. JEM, } \\
\text { SLA rebel } \\
\text { groups }\end{array}$ & $\begin{array}{l}\text { hakura, } \\
\text { access, } \\
\text { homeland, } \\
\text { tribal land. }\end{array}$ & $\begin{array}{l}\text { Customary, } \\
\text { Colonial, } \\
\text { Statutory, } \\
\text { Islamic }\end{array}$ & $\begin{array}{l}\text { destruction of } \\
\text { hakura= land } \\
\text { takings }\end{array}$ & Label \\
\hline Colombia & $\begin{array}{l}\text { Govt. vs. } \\
\text { FARC rebels } \\
\text { vs. para- } \\
\text { military } \\
\text { groups }\end{array}$ & $\begin{array}{l}\text { occupation, } \\
\text { abandoned, } \\
\text { indigenous, } \\
\text { displaced. }\end{array}$ & Statutory & $\begin{array}{l}\text { occupation= } \\
\text { dislocation, } \\
\text { land takings }\end{array}$ & Action \\
\hline Liberia & $\begin{array}{l}\text { Govt vs. Tay- } \\
\text { lor's rebels; } \\
\text { Taylor govt. } \\
\text { vs. LURD } \\
\text { rebels }\end{array}$ & $\begin{array}{l}\text { customary } \\
\text { law, } \\
\text { clan, property, } \\
\text { adequate } \\
\text { area, essen- } \\
\text { tial activities. }\end{array}$ & $\begin{array}{l}\text { Multiple cus- } \\
\text { tomary, } \\
\text { State spon- } \\
\text { sored cus- } \\
\text { tomary, } \\
\text { Statutory. }\end{array}$ & $\begin{array}{l}\text { customary } \\
\text { law, adequate } \\
\text { area, essen- } \\
\text { tial activities= } \\
\text { land takings \& } \\
\text { retakings. }\end{array}$ & Label \\
\hline Yemen & $\begin{array}{l}\text { Govt. vs. al- } \\
\text { Hirak south- } \\
\text { ern seper- } \\
\text { atists, vs. al- } \\
\text { Qaeda }\end{array}$ & $\begin{array}{l}\text { Sultanate } \\
\text { land, } \\
\text { state land, } \\
\text { private land, } \\
\text { tenant land. }\end{array}$ & $\begin{array}{l}\text { Socialist era, } \\
\text { Post-unifica- } \\
\text { tion statutory, } \\
\text { Islamic. }\end{array}$ & $\begin{array}{l}\text { Sultanate } \\
\text { land= retaking } \\
\text { land. }\end{array}$ & Label \\
\hline $\begin{array}{l}\text { Israel/Pa- } \\
\text { lestine }\end{array}$ & $\begin{array}{l}\text { Israeli govt. } \\
\text { vs. Palestin- } \\
\text { ian groups } \\
\text { (PA, Hamas) }\end{array}$ & $\begin{array}{l}\text { settlement, } \\
\text { transfer, } \\
\text { absenteeism }\end{array}$ & $\begin{array}{l}\text { Colonial, } \\
\text { Israeli, } \\
\text { Ottoman, } \\
\text { Customary. }\end{array}$ & $\begin{array}{l}\text { Settlement, } \\
\text { transfer, ab- } \\
\text { sentee= land } \\
\text { takings. }\end{array}$ & Action \\
\hline $\begin{array}{l}\text { Sierra } \\
\text { Leone }\end{array}$ & $\begin{array}{l}\text { Govt. \& cus- } \\
\text { tomary } \\
\text { leadership } \\
\text { vs. militias }\end{array}$ & $\begin{array}{l}\text { sell, } \\
\text { transfer, } \\
\text { exclusion }\end{array}$ & $\begin{array}{l}\text { Customary, } \\
\text { Statutory }\end{array}$ & $\begin{array}{l}\text { Sell, } \\
\text { Native }\end{array}$ & Action \\
\hline
\end{tabular}


